\title{
Pathology mimicking distal intestinal obstruction syndrome in cystic fibrosis
}

\author{
A M Dalzell, D P Heaf, H Carty
}

\begin{abstract}
Eight patients with cystic fibrosis had chronic abdominal pain and the other features of distal intestinal obstruction syndrome. Coexistent abdominal pathology was shown in six patients. Two had a small bowel volvulus, and the others had Crohn's disease, a small bowel fistula, appendix abscess, and an ovarian dermoid. Opiate abuse exacerbated symptoms in two other patients.
\end{abstract}

Cystic fibrosis is a multiorgan disorder, and many gut related problems have been described. ${ }^{1}$ Abdominal pain is a common symptom and when associated with a right lower quadrant mass and characteristic features on plain abdominal radiography ${ }^{2}$ it constitutes the distal intestinal obstruction syndrome. The cause of this essentially chronic condition is unknown, but the symptoms and signs are due to partial or complete obstruction of the intestinal lumen in the ileocaecal region by inspissated material. It affects approximately $15 \%$ of patients, and is only temporarily relieved by gastrointestinal lavage. Other abdominal conditions have been described in patients with cystic fibrosis, ${ }^{3}$ and could be confused with the distal intestinal obstruction syndrome. We reviewed the case histories of patients who had been initially diagnosed as having distal intestinal obstruction syndrome, and describe cases where alternative pathology was found.

\section{Case reports}

Eight of 32 patients (25\%) thought to have distal intestinal obstruction syndrome showed alternative pathology. There were five boys and three girls. All patients had recurrent abdominal pain and a right iliac fossa mass palpable periodically. All took pancreatic enzyme supplements because of malabsorption. Clinical features are outlined in the table.

Coexistent disease in eight patients with distal intestinal obstruction syndrome and cystic fibrosis
This boy failed to thrive from birth and had abdominal distension and disturbed bowel habit. Distal intestinal obstruction syndrome was diagnosed at 12 months. At 3 years of age small bowel overgrowth was demonstrated, and a barium enema suggested a redundant small bowel loop. A small bowel fistula was excised at operation and his symptoms were abolished.

CASE 2

From the age of 5 years this girl was said to suffer distal intestinal obstruction syndrome. She had severe abdominal pains, a right iliac fossa mass, failed to thrive, and rarely attended school. An acute exacerbation of intestinal obstruction at 15 years prompted a diagnostic contrast study, which suggested a stricture in the ileocaecal region; this was excised and showed Crohn's disease. Symptoms completely resolved and she subsequently thrived.

\section{CASE 3}

A 13 year old boy had a right iliac fossa mass for five years with intermittent abdominal pain. An acute exacerbation treated as distal intestinal obstruction with oral diatrizoate did not resolve, and an abdominal ultrasound examination showed an appendix abscess. He was managed conservatively and underwent an interval appendicectomy. He continues to have a right iliac fossa mass and abdominal pain.

CASE 4 five year lapse. His major concern was bouts of severe abdominal pain. His abdomen was heavily loaded with faeces, and was unresponsive to treatment. He continued to take $40 \mathrm{mg}$ methadone a day because of opiate addiction,

\begin{tabular}{|c|c|c|c|c|c|c|c|}
\hline \multirow{2}{*}{$\begin{array}{l}\text { Royal Liverpool } \\
\text { Children's Hospital, } \\
\text { Respiratory Unit } \\
\text { A M Dalzell } \\
\text { D P Heaf }\end{array}$} & \multicolumn{7}{|c|}{ Coexistent disease in eight patients with distal intestinal obstruction syndrome and cystic fibrosis } \\
\hline & $\begin{array}{l}\overline{\text { Case }} \\
\text { No }\end{array}$ & $\begin{array}{l}\text { Current age } \\
\text { (years) }\end{array}$ & $\begin{array}{l}\text { Age when cystic } \\
\text { fibrosis diagnosed } \\
\text { (years) }\end{array}$ & $\begin{array}{l}\text { Presenting features } \\
\text { of cystic fibrosis }\end{array}$ & $\begin{array}{l}\text { Duration of distal } \\
\text { intestinal obstruction } \\
\text { syndrome symptoms } \\
\text { (years) }\end{array}$ & Secondary diagnosis & $\begin{array}{l}\text { Outcome of } \\
\text { distal intestinal } \\
\text { obstruction syndrome }\end{array}$ \\
\hline $\begin{array}{l}\text { Radiology } \\
\text { H Carty } \\
\text { Correspondence to: }\end{array}$ & $\begin{array}{l}1 \\
2 \\
3\end{array}$ & $\begin{array}{r}5 \\
15 \\
13\end{array}$ & $\begin{array}{l}\text { Birth } \\
4 \\
6.5\end{array}$ & $\begin{array}{l}\text { Meconium ileus } \\
\text { Failure to thrive } \\
\text { Respiratory }\end{array}$ & $\begin{array}{r}3 \\
10 \\
5\end{array}$ & $\begin{array}{l}\text { Small bowel fistula } \\
\text { Crohn's disease } \\
\text { Appendix abscess }\end{array}$ & $\begin{array}{l}\text { Resolved } \\
\text { Resolved } \\
\text { Unresolved }\end{array}$ \\
\hline $\begin{array}{l}\text { Dr A M Dalzell, } \\
\text { The Royal Children's } \\
\text { Hospital, }\end{array}$ & 4 & 22 & 0.2 & $\begin{array}{l}\text { infections } \\
\text { Sibling had cystic } \\
\text { fibrosis }\end{array}$ & 5 & Opiate addiction & Unresolved \\
\hline $\begin{array}{l}\text { Hospital, } \\
\text { Herston Road, } \\
\text { Brisbane, } \\
\text { Queensland 4029, } \\
\text { Australia. }\end{array}$ & $\begin{array}{l}5 \\
6 \\
7\end{array}$ & $\begin{array}{l}22 \\
15 \\
12 \cdot 5\end{array}$ & $\begin{array}{l}0.5 \\
5 \\
\text { Birth }\end{array}$ & $\begin{array}{l}\text { fibrosis } \\
\text { Diarrhoea } \\
\text { Pancreatitis } \\
\text { Meconium } \\
\text { peritonitis }\end{array}$ & $\begin{array}{r}10 \\
10 \\
2\end{array}$ & $\begin{array}{l}\text { Opiate abuse } \\
\text { Ovarian dermoid } \\
\text { Peritoneal adhesions }\end{array}$ & $\begin{array}{l}\text { Unresolved } \\
\text { Resolved } \\
\text { Resolved }\end{array}$ \\
\hline $\begin{array}{l}\text { quary } 1990 \\
990 ; 65: 540-1)\end{array}$ & 8 & Died & Birth & Meconium ileus & 2 & Volvulus & $\begin{array}{l}\text { Died four months } \\
\text { after operation }\end{array}$ \\
\hline
\end{tabular}

\footnotetext{
Royal Liverpoo Children's Hospital, H Carty

The Royal Children'

Brisbane,

Australia.

(ArchDis Child 1990;65.540-1)
} 
and he still has severe intermittent abdominal pain and a right iliac fossa mass.

CASE 5

This girl developed diabetes mellitus at 15 years, and was insulin dependent. Abdominal pains began at 12 years of age associated with a right iliac fossa mass. She used a variety of analgesics in order to control abdominal pain, including black market opiates. Distal intestinal obstruction syndrome continues to be a problem.

CASE 6

This patient was diagnosed as having cystic fibrosis after recurrent admissions with abdominal pain associated with pancreatitis. A lower right quadrant abdominal mass and persistent abdominal pain was diagnosed and treated as distal intestinal obstruction syndrome for five years. At 15 years of age an abdominal radiograph suggested the presence of a right ovarian dermoid cyst, which was removed. The symptoms of distal intestinal obstruction syndrome have resolved.

\section{CASES 7 AND 8}

Both these children were diagnosed as having cystic fibrosis at birth with meconium ileus. Both developed a right iliac fossa mass and recurrent abdominal pains and were diagnosed as having distal intestinal obstruction syndrome before peritoneal adhesions and volvulus, respectively, were shown to be the cause of symptoms. Case 7 has been asymptomatic since operation. Case 8 died four months postoperatively because of progressive respiratory failure.

\section{Discussion}

Abdominal pain occurs in many patients with cystic fibrosis. Distal intestinal obstruction probably accounts for the symptoms in many individuals, but other conditions mimic some of the features. If misdiagnosed, this not only leads to ineffective treatment, but can prolong unnecessary misery for individuals who already have a chronic illness. The cause of distal intestinal obstruction syndrome is probably multifactorial, and prolonged orocaecal transit time, ${ }^{4}$ hyperacidity in the small bowel, and pancreatic enzyme manipulation, ${ }^{5}$ may be important influences.

Of the eight patients described, symptoms have resolved in four. The removal of a diseased appendix would not be expected to influence the symptoms and signs of distal intestinal obstruction syndrome, and it seems unlikely that the removal of an ovarian dermoid contributed to the improvement experienced by case 6. Baxter et al noted four previous cases of Crohn's disease occurring in patients with cystic fibrosis including their $\mathrm{own}^{3}$; complications after surgically treated meconium ileus have been previously described.

It is not surprising that symptoms of distal intestinal obstruction syndrome persist in cases 4 and 5 because of the constipating effect of opiates, which have been noted to worsen distal intestinal obstruction syndrome. ${ }^{6}$ Both patients remain severely symptomatic despite therapeutic manoeuvres with $\mathrm{H}_{2}$ receptor blockers, promotility agents, and pancreatic enzyme manipulations.

We report these cases in order to stress the importance of keeping an open mind as to the possibility of secondary pathology when children with cystic fibrosis present with abdominal pain. Close cooperation between the physician and radiologist is essential. All children with apparent distal intestinal obstruction syndrome should have a complete abdominal ultrasound examination to confirm that the gall bladder, renal tract, and pelvic organs are normal and to exclude an abscess. The choice of medium for contrast studies must be discussed and measures taken to prevent the complication of barium impaction if it is used. These children were mostly investigated with dilute barium.

Almost half of our patients with clinical distal intestinal obstruction syndrome and secondary pathology presented with meconium ileus and acquired complications related to abdominal surgery. We are now more cautious in diagnosing distal intestinal obstruction syndrome in patients with cystic fibrosis and are keen to discount exacerbating factors and underlying conditions, particularly in patients who have had previous surgery. There is a great need to discover the reasons why distal intestinal obstruction syndrome occurs, and a more effective way of treating it.

AMD is in receipt of a cystic fibrosis research fellowship.

1 Park RW, Grand RJ. Gastrointestinal manifestations of cystic fibrosis: a review. Gastroenterology 1981;81:1143-61.

2 Pilling DW, Steiner GM. the radiology of meconium ileus equivalent. Br $\mathcal{F}$ Radiol 1981;54:562-5.

3 Baxter PS, Dickson JA, Variend S, Taylor CJ. Intestinal disease in cystic fibrosis. Arch Dis Child 1988;63:1496-7.

4 Bali A, Stableforth D, Asquith P. Prolonged small-intestinal Bali A, Stableforth D, Asquith P. Prolonged small-intestinal
transit time in cystic fibrosis. $\mathrm{Br}$ Med $\mathcal{f} 1983 ; 287: 1011-3$. 5 Rosenstein BJ, Langbaum TS. Incidence of distal intestinal obstruction syndrome in cystic fibrosis. $\mathcal{F}$ Pediatr Gastroenterol Nutr 1983;2:299-301.

6 Rosenberg E, Schmerling DH. The meconium ileus equivalent in mucoviscidosis. Klin Padiatr 1983;195:323-9. 